\title{
The Survival of Embroidery Industry in Tasikmalaya: Moral Ethics Study on Islamic and Sundanese Economics
}

\author{
Dr. Joharotul Jamilah \\ Department of Political Science, Faculty of Social and Political Sciences UIN Jakarta, Indonesia \\ joharotul.jamilah@uinjkt.ac.id
}

\begin{abstract}
The development of the local economy in Tasikmalaya can be noticed by the emergence of embroidery entrepreneurs. The start of the entrepreneur among the Sundanese in that area comprises two dimensions of social sustainability. Based on the social role of the local entrepreneur class in Tasikmalaya, it can be concluded that this local entrepreneur class present and develop in the context and as a supporter of the local economy, with the social formation characteristic of the typical local entrepreneur (hybrid). This research shows that the local entrepreneurs can get up and grow (survive) with the intervention from the state. The role of the government in the economic resilience of the embroidery industry in Tasikmalaya is seen through the promotion efforts at the local and international level, network development, and arrangement of training for the workers. The business grows progressively following global competition through the sales expansion in national and international scale and participate in sustaining the nation's economic adversity during the 1997/1998 and 2008 economic crisis. This study uses the qualitative approach with case study method. They did not only contribute to the development of local economic development but also become the motor of the socio-economic transformation of Tasikmalaya Sundanese Society from an the agrarian society into an industrial society.
\end{abstract}

Keyword - local economy, survive, intervention of state

\section{INTRODUCTION}

In Indonesia, small and medium-sized enterprises (SMEs) play a very important and strategic role in economic development. In addition, due to its rising revenue, SMEs also have a role in income equalization. Based on data collected by the Ministry of Cooperative and SMEs in 2010, SMEs showed a dominant existence in the Indonesian economy. First,the high number of the big industry in every economic sector. Second, its big potency for employment (reduce the number of unemployment and poverty). Third, SMEs significant contribution in building the growth domestic product (GDP) is 56\% from GDP total in 2010 [1].

Besides those that grow well, some of the SMEs in Indonesia were unable to survive and facing failure. The first 5 years were the critical year for a company. More than 50\% of small enterprises were failed to pass the second year. Some of the small business can go forward but then failed soon as it reached a bigger scale. However, there are also small enterprises that manage to be successful due to the good management by its owner.

The factors causing the failure including the prolonged economic crisis which threatens the existence of SMEs due to the decreased of purchasing capabilities as people tend to choose basic needs prioritizing, the rise of raw material prices (mainly from imports), the difficulties in marketing, the difficulties in obtaining a loan, and the limited access to information were threatened the existence of small industries [2].

One of the SMEs which survived and well developed is the embroidery industry in Tasikmalaya. Up to 2014, the number of embroidery industry in Tasikmalaya has reached 1,371 unit, including 13,856 labor. Compared to 2010, when the number of embroidery industry in Tasikmalaya has just reached 1,252 unit which involved 12,201 labor.[3]The data showed $9.5 \%$ increase of embroider industry in Tasikmalaya over the past five years. On the other hand, --although there is no definitive data-many of the embroidery SMEs in Tasikmalaya were facing failures.

Tasikmalaya has developed the embroidery business for generations since the early $20^{\text {th }}$ century. The embroidery business in Tasikmalaya experienced a quite interesting dynamics to be studied. The development of embroidery industry in Tasikmalaya was seemingly unaffected by the economic crisis which led to the expectation that the economic acts undertaken by SMEs embroidery are not solely based on formal economy rationality [4], but also by other aspects [5]. It is known that the embroidery business in Tasikmalaya has a close relationship with the religious institutions such as schools that are infused with the values of Islam [6]. Moreover, the background culture of the Sundanese is also suspected to affect the actions of embroidery employers. 
This is in line with the phenomena that occur in a typical regional business that emphasizes the moral ethics above the formal rational, for instance, among the Wajo [7] trader and businessman Gu-lakudo ethnic, [8] and the fishponds businessman in Delta Mahakam. [9] The economic acts of these entrepreneurs have some different tendencies compared to the general habits of a businessman. The social relations of patron-client [10] were bonded by the Islamic moral values and Bugis culture. Likewise, with Tasikmalaya that has a strong social, religious and cultural background that influence people's behavior. This raises the question, does religious ethics and culture affect economics action in Tasikmalaya embroidery entrepreneurs so that they can survive?

The way actors perform the economics actions in society cannot be explained by referring to the individual motives or values espoused alone; it should also consider the network of social relations and social institutions. For example, the kinship system among the cinnamon seller in market of Nagari and the family ties and kinship of Bawean people in Malaysia which forms a network that becomes a strategy for economic development. Therefore the economics action is inseparable from the employers' social background, religion and culture, even though the embeddedness was over and under embedded of continuum line [11]. This is relevant to analyze the contexts of the survival of economic life in embroidery society at Tasikmalaya, associated with economic acts relating to religious values and traditional customs value. The values embodied in the moral ethics affect the economics action of the employers. Moral ethics based on the values of Islam are justice, hard work (effort), trustworthy (honest), patient, sincerity, and good deeds [12]. Cultural values are mutual love, mutual coaching, mutual caring, intimacy (togetherness), uphold goodness, respect rights, and maintaining a modest lifestyle [13].

Based on the backgrounds and theories above, this article aims to analyze the Tasikmalaya embroidery entrepreneurs who can survive and the extent of moral and formal value underlying their economics action.

\section{METHODS}

This study uses the qualitative approach with case study method. This research was conducted for one year, started from September 2014 to December 2015, at Kawalu district, Tasikmalaya, West Java. The subjects of this research are 16 entrepreneurs who are determined by criteria; a) employers who have more than 15 years, or more than one generation; $b$ ) based on Law No. 20 Year of 2008 for the SMEs criteria. The process of selecting the sixteen entrepreneurs was done through the snowballing method. Data were collected through interviews and observation, while data triangulation was also done during the data collection.

\section{RESULT AND DISCUSSION THE TYPOLOGY OF EMBROIDERY ENTREPRENEURS IN TASIKMALAYA}

The persistence of the embroidery industry economy in Tasikmalaya cannot be separated from the dynamics of the embroidery entrepreneurs with the emergence and failures of various types of entrepreneurs. This typology of entrepreneurship form is based on the over embeddedness or under embeddedness [14] of the economics ethics of Islam and Sundanese values on the entrepreneurs' economic acts. The types are Sundanese Entrepreneur Religious Culturalist (SERC) whom the economics act over embedded on Islam and Sunda values, Sundanese Entrepreneur Religious (SER) whom over embedded with Islam ethics and not strongly affected by Sunda economics ethics, Sundanese Entrepreneur Culturalist (SEC) whom over embedded with Sundanese culture ethics and under embedded by theIslam ethics, and Sundanese Entrepreneur Modern (SEM) whom under embedded by both of the ethics (Islam and Sunda) but over embedded on market economy ethics (modern). The formation of entrepreneur's typology explained in Table 1 .

\section{Table 1. Matrix of the typology of embroidery entrepreneur in Tasikmalaya}

\begin{tabular}{|c|c|c|}
\hline Sundanese Culture & \multicolumn{2}{|c|}{ Islamic Ethics } \\
\cline { 2 - 3 } Ethics & Over & Under \\
\hline Over & SERC & SEC \\
\hline Under & SER & SEM \\
\hline
\end{tabular}

Source: Primary data, 2015

To prove whether the persistence of the embroidery industry for economic action embedded with Islam ethics and Sunda ethics, assuming that the SERC type (over embedded with Islam ethics and Sunda ethics) is the most likely to survive with the biggest production values and the most stable on dynamics that is equal to big entrepreneurs, it can be seen through several aspects; first, the business duration time which divided into three categories, survive enough (15-25 years), survive (26-40 years) and further ( $>40$ years). Second, business size in a year based on UU SMEs year 2008, consist of micro-entrepreneurs (production value $<300$ million), small entrepreneurs (300 million - 2.5 billion), and middle entrepreneurs ( 2.5 billion - 50 billion). Third, whether the business dynamics, it could be either stable, dynamic or very dynamic. 
Table 2. The matrix of the typology of embroidery entrepreneur based on business duration time, business size, and business dynamics.

\begin{tabular}{|c|c|c|c|c|}
\hline & SERC & SEC & SER & SEM \\
\hline $\begin{array}{l}\text { Business duration } \\
\text { time: } \\
\text { 1. Survive enough (1) } \\
\text { 2. Survive (2) } \\
\text { 3. Further (3) } \\
\end{array}$ & $\begin{array}{c}1,2, \\
\text { and } 3\end{array}$ & 1 & 1 & 1 \\
\hline $\begin{array}{l}\text { Business size: } \\
\text { 1. Micro (1) } \\
\text { 2. Small (2) } \\
\text { 3. Middle (3) } \\
\end{array}$ & 3 & 1 and 2 & 2 and 3 & $\begin{array}{c}1,2 \\
\text { and } 3\end{array}$ \\
\hline $\begin{array}{l}\text { Business dynamics: } \\
\text { 1. Stable (1) } \\
\text { 2. Dynamic (2) } \\
\text { 3. Very dynamic (3) }\end{array}$ & 1 and 2 & 1 & 2 and 3 & 3 \\
\hline
\end{tabular}

Source: Primary data, 2015

Based on Table 1 and Table 2, the business duration time category on SERC entrepreneurs quite varied (survive enough, survive and further), besides the rest concentrated on surviving enough category. It can be concluded that the business duration did not affect the survival of embroidery industry in Tasikmalaya, because of the various type of business duration time on SERC entrepreneur. Based on the business size, SERC was on middle entrepreneur category with the highest production value, while SEM own all the business size category. The SER belong to small and middle entrepreneur, while SEC belongs to micro and small entrepreneur. Hence, the business size did not affect the survival of embroidery industry but was affected by the embeddedness of Islam and Sunda ethics on the entrepreneur economic acts (SERC type). On the other hand, based on the business dynamics, SERC own two categories, stable and dynamic. SEC belong to the dynamic and very dynamic category, and SER and SEM belong to the stable and very dynamic category. The business dynamics of SEM was interestingly very dynamic which was shown by the drastic up and down of the business, in different with SEC which stable on the dynamics. Based on the survival indicator (business duration time, business size and business dynamics), the economics of embroidery industry in Tasikmalaya were affected by religious ethics (Islam) and culture ethics (Sunda) because of the prove on SERC entrepreneurs (strongly embedded with religious ethics and Sunda ethics) who were survive the longest, include on middle entrepreneurs (the highest on production values), and stable (the business stable on top) and dynamic (the up and down is not drastic) on dynamics.

\section{EMBEDDEDNESS FORM OF ISLAMIC ETHICS AND SUNDA ETHICS ON ECONOMIC ACTS OF EMBROIDERY ENTREPRENEUR IN TASIKMALAYA}

In Islam theory, every economic activity both personal and in the society are the unseparated part of religious life. Islam organizes all kinds of relationship either between human and the Lord (hablumminallah) or among humans (hablumminannas). Islam puts morality and rationality as a frame for the calculation of profit and loss based on considerations of economic rationality. Islam responds to the presence of economic institutions (such as the market) as a legal (halal)and good (tayyib) venue for trade transactions, because people need to get the allocated and distributed economy source. In essence, humans have a role in managing the economic resources to meet the basic principles of fairness, rationality, moral values and ethical life.

In essence, socio-economic relations formed because of the economic, social networks of embroidery entrepreneurs associated with the production, financing, and marketing. In the relations of production, businessman relates to workers, for workers who are inside or workers who are outside. In the field of capital, entrepreneurs correlated with the cloth merchants and banks, and in the areas of marketing, entrepreneurs in touch with collectors and traders in the market. Entrepreneurs also related to the society around regions. Socio-economic relations can be seen by the Table 3 .

Table 3. Matrix of socio-economic relation of embroidery entrepreneurs

\begin{tabular}{|c|c|c|c|c|}
\hline \multirow{2}{*}{$\begin{array}{c}\text { Socio- } \\
\text { economic } \\
\text { relation of the } \\
\text { entrepreneurs }\end{array}$} & SERC & SER & SEC & SEM \\
\cline { 2 - 5 } & Partners & $\begin{array}{c}\text { Extended } \\
\text { family }\end{array}$ & Partners & $\begin{array}{c}\text { Patron- } \\
\text { Client }\end{array}$ \\
\hline Workers & Friends & Friends & Friends & Competitor \\
\hline $\begin{array}{c}\text { Other } \\
\text { entrepreneurs }\end{array}$ & Partners & Partners & Partners & Partners \\
\hline Traders & Partners & Partners & Partners & Partners \\
\hline Financier & $\begin{array}{c}\text { Comrade } \\
\text { and } \\
\text { Local society }\end{array}$ & Comrade & Family & Partners \\
\hline
\end{tabular}

Source: Primary data, 2015

Based on Table 3., the ethics isomorphism can be seen on SERC, SEC and SER entrepreneurs who treat workers, traders, and financier as a partner, and treat the other entrepreneurs as friends. The SEM entrepreneurs have socioeconomic relations with workers as patron-client, superiors, and inferiors (although still need each other), while the relationship with the other entrepreneurs is a competitor, but still being a partner with traders, financer, and local society. These socio-economic ethics confirm that the SEM entrepreneurs embedded only with economic value, while the others types of entrepreneurs embedded with either Islam 
ethics, Sunda ethics or both. SEC entrepreneurs embedded with Sunda value in a working relationship with his work.

Based on the above statement, HJJ economic acts are affected by Sunda value, as the Sundanese expression "bengkung ngariung, bongkok ngaronyok" meaning to feel the difficulty and happiness, never own profit alone equally, but share the profit with all of the workers. This is matched with the Sundanese people view.

Likewise, socio-economic relations are intertwined with the surrounding community that treats them as family and relatives apparent from the remarks one of SERC entrepreneurs

From the statement above, HMG economic acts on SEC type was affected by religious values and cultures values. The linkage is very clear between both of the ethics, from the Sundanese expression that associated with Islam thoughts.

\section{CONCLUSION}

The embeddedness of embroidery entrepreneur's economic acts to the Islam values and Sundanese culture values creates some forms of embeddedness with kinds of characteristics. There is a various level of embeddedness from the over until the under embeddedness.

Based on the strong and weak of the embeddedness on Islam ethics and Sunda ethics, there are four typologies of embroidery entrepreneurs. They are the SERC type whose business characteristics are the most likely to survive, developing, has the highest production value, and stable dynamics similar to the middle entrepreneurs; the SER type whose business characteristics are tfair survival, mix of small middle size entrepreneurs, and dynamic; the SEC type whose business characteristics are having fair survival, consisted by the mix of micro entrepreneurs and small entrepreneurs, and stagnant; and the SEM type whose business characteristics are fair survival, mix of micro to middle entrepreneurs, and very dynamic (but not extremely up and down).

The embeddedness of Islam and Sundanese values in economic acts of embroidery entrepreneurs in Tasikmalaya can be seen on the entrepreneur's characteristics who always survive. Entrepreneurs who always survive own characteristics: do business with religion and culture as the basis, treat workers as partners because the need of each other to create mutual benefit, uphold equality, consider that the profits are not solely used to enrich themselves but to share religious and social interests as well as to maintain harmonious relationship with others.

\section{References}

[1]Ministry for Cooperative and SMEs,www.depkop.go.id. 2014.

[2] Nagib, L, et al. Keberlangsungan Hidup dan Pengembangan Industri Kecil di Tengah Krisis: Kajian Cepat di Kabupaten Tasikmalaya, PPT -LIPI, 2000.

[3] Cooperatives, SMEs, Trade and Industry Service Tasikmalaya City, 2014

[4] Weber, Max.Economy and Society: An Outline of Interpretive Sociology, Vol IUniversity of California Press Berkeley, 1978.

[5] Scott, JC. Moral Ekonomi Petani. Pergolakan dan Subsistensi di Asia Tenggara. Jakarta; LP3ES, 1994.

[6] Lubis, NH, et al.Sajarah Perkembangan Islam di Jawa Barat, Yayasan Masyarakat Sejarawan ndonesia Cabang Jawa Barat, 2011.

[7] Syukur, M. Sistem Ekonomi Lokal Masyarakat Bajo: (Studi Kasus pada Penenun di Kabupaten Wajo Provinsi Sulawesi Selatan). IPB: Disertasi, 2013.

[8] Malik ML. Etos Kerja, Pasar dan Masjid: Studi Sosiologi MobilitasPerdagangan Orang Gu-Lakudo di Sulawesi Tenggara. Depok: Disertasi PPs Sosiologi Fisip UI, 2010.

[9] Lenggono, SP. Ponggawa dan Patronase Pertambakan di Delta Mahakam: Teori Pembentukan Ekonomi Lokal. Disertasi, IPB, Bogor, 2011.

[10] Scott, JC. Moral Ekonomi Petani. Pergolakan dan Subsistensi di Asia Tenggara. Jakarta; LP3ES, 1994.

[11] Granovetter, M. "Economic Action and Social Structure: The Problem of Embeddedness. J American Journal of Sociology". Vol. 91, pp. 481-510, 1985.

[12] Rahardjo, M Dawam.Etika Ekonomi dan Manajemen, Yogyakarta: Tiara Wacana, 1990.

[13] Warnaen, S. et al.Pandangan Hidup Orang Sunda Seperti Tercermin Dalam Tradisi Lisan dan Sastra Sunda. Hasil Penelitian. Bandung: Pusat Studi Sunda (Sundanologi), 1987.

[14] Granovetter, M., Sweddberg, R (edit).The Sociology of Economic Life. (edit). Boulder, San Francisco, Oxford (US): Westview Pr, 1992. 